\title{
Emergency contraception: an untapped resource among sexually active college students in Osogbo metropolis, Nigeria
}

This article was published in the following Dove Press journal:

Open Access Journal of Contraception

19 April 2013

Number of times this article has been viewed

\author{
Esther O Asekun- \\ Olarinmoye ${ }^{\prime}$ \\ Wasiu O Adebimpe' \\ Adeleye A Adeomi² \\ Adenike I Olugbenga-Bello² \\ 'Department of Community Medicine, \\ Osun State University, Osogbo, \\ Nigeria; ${ }^{2}$ Department of Community \\ Medicine, Ladoke Akintola University \\ of Technology Teaching Hospital, \\ Ogbomoso, Nigeria
}

\begin{abstract}
Introduction: Unwanted pregnancies and unsafe abortions result in the death of thousands of women, while millions suffer from permanent or temporary disabilities, problems that the use of emergency contraception can ameliorate. This study was therefore carried out to assess the knowledge, attitude, and practice of emergency contraception (EC) among college students in Osogbo metropolis.
\end{abstract}

Materials and methods: This descriptive cross-sectional study was carried out among 594 college students in Osogbo metropolis in Osun State, Nigeria, using pretested, semistructured questionnaires. Respondents were selected by multistage sampling. Data were analyzed using SPSS software, version 15.

Results: The mean age of the respondents was $23.45 \pm 3.63$ years. Mean age at first sexual exposure was $19.34 \pm 4.34$ years. Awareness about EC was fairly high among the respondents, $(403,67.8 \%)$, with categorized scoring of outcome variables showing that $60.8 \%$ of respondents had good general knowledge and only $27.9 \%$ had a positive attitude towards EC. However, only 66 (29.9\%) of the sexually active respondents had ever used EC before the study, while $26(21.5 \%)$ of the 121 sexually active female respondents admitted to having had an abortion. Bivariate analysis revealed that respondents' knowledge of, and attitude towards, EC were significantly related to age $(P<0.00000001)$, respondents' course of study $(P<0.00000001)$, and their level in college $(P=0.0000002)$, while the use of EC among the sexually active students was significantly related to respondents' knowledge of EC $(P=0.017)$.

Conclusion: Fairly high awareness, good general but poor comprehensive knowledge, negative attitudes, and poor use characterized the practice of EC among our study population. There is therefore a need for health-education initiatives about EC, addressing specific areas of poor knowledge and clarification of common misconceptions.

Keywords: knowledge, attitude, practice, college students, emergency contraception

\section{Introduction}

Emergency contraception (EC) refers to a group of birth-control modalities that when used after an unprotected intercourse and within defined time limits can prevent an unwanted pregnancy. ${ }^{1,2}$ EC remains the only form of hormonal contraception that can reduce the risk of pregnancy after unprotected sexual intercourse, when a planned contraceptive method (like condoms) fails, or in cases of rape. Increasing the availability and promotion of EC, therefore, has the potential to reduce the incidence of unintended pregnancies if used correctly, and in turn reduce associated social and health-care costs. ${ }^{3-5}$
Correspondence: Esther O AsekunOlarinmoye

Department of Community Medicine, College of Health Sciences, Osun State University, Osogbo, Osun State, Nigeria Email esther.asekun-olarinmoye@ uniosun.edu.ng 
EC has been found to be a safe, effective, and cheap way to prevent unintended pregnancies, and its appropriate use could prevent up to $75 \%$ of unplanned pregnancies. ${ }^{6,7}$ However, EC is largely underutilized worldwide and has been referred to as one of the best-kept secrets in reproductive health. ${ }^{2,8,9}$ Each year, about 210 million women around the world become pregnant. ${ }^{10}$ Among them, about 75 million pregnancies (36\%) are unplanned and/or unwanted. ${ }^{11}$ It is estimated that between 8 and 30 million pregnancies each year result from contraceptive failure, either due to inconsistent or incorrect use of contraceptive methods or failure of the method itself. ${ }^{12}$

Unintended pregnancy poses a major challenge to reproductive health in developing countries. ${ }^{13}$ Nigeria currently has one of the highest rates of maternal mortality in the world,${ }^{14}$ and about $40 \%$ of these maternal deaths are due to complications of unsafe abortions as a response to unwanted pregnancy. ${ }^{15,16} \mathrm{EC}$ may therefore be an effective way to reduce maternal mortality, by reducing the number of unwanted pregnancies and induced abortions in the country. ${ }^{13}$

One of the groups that are particularly vulnerable to unsafe abortions is young people (10-24 years). This is a period of psychological, social, and sexual changes associated with experimentation and discovery. Because of this, they are exposed to such risks as unwanted pregnancies. ${ }^{2}$ Adolescent and young adult women are characteristically less consistent users of contraception, they perceive higher barriers to accessing reproductive care, and they are more likely to report having either sporadic sex or sex that is initiated under the influence of alcohol, especially when first becoming sexually active. ${ }^{17} \mathrm{EC}$ is an effective compensatory method to prevent pregnancy following unprotected intercourse and is increasingly available to this group of women. ${ }^{17}$

In a Nigerian study, a total of $76.4 \%$ of the respondents were aware of EC, but only $18.5 \%$ of the sexually experienced students had used EC pills previously. ${ }^{18}$ However, an increasing trend of awareness but persistent low utilization of EC among youths has been reported by several other studies within and outside Nigeria. ${ }^{19-21}$ A major barrier to the use of EC is lack of relevant and appropriate knowledge about EC. ${ }^{22}$ In many low-income countries, the lack of knowledge about and access to EC may result in women resorting to unsafe abortions, which contribute significantly to maternal morbidity and mortality. ${ }^{23}$ Baseline information that could guide awareness-creation efforts and policy decisions are mandatory in order to assist women in making informed choices. This study was therefore carried out to assess the knowledge, attitude and practice of EC among college students in Osogbo metropolis, Nigeria, with a view to making necessary recommendations that would further help to reduce maternal mortality in Nigeria.

\section{Materials and methods \\ Study area}

The study was carried out in Osogbo, the capital of Osun State. It was conducted among both males and females in three colleges in Osogbo metropolis, namely College of Health Sciences, Ladoke Akintola University of Technology (LAUTECH), the Osun State School of Nursing, Asubiaro, and Osun State University, Osogbo campus. There are about twelve primary health care centers and one general and one teaching hospital within the metropolis. There are numerous community pharmacy shops where EC can be purchased by women in Osogbo.

\section{Study design and population}

This was a descriptive cross-sectional study of EC use among college students. These were registered students of any of the three colleges that took part in the study.

\section{Sampling size estimation}

Using the formula for calculation of minimum sample size for population $>10,000$ and an EC use prevalence rate of $35.5 \%,{ }^{13}$ a minimum sample size of 352 was calculated. This sample size was increased to 600 in order to make allowance for respondents' nonresponse and give proper and larger representation.

\section{Sampling method}

The multistage sampling technique was used to select the respondents. One faculty per college was selected using random sampling employing simple balloting. In stage two, two departments per faculty were selected using random sampling employing simple balloting. In stage three, two classes/arms were selected per department using random sampling employing simple balloting. In stage four, a systematic sampling of one in three students based on their sitting arrangement for that day was used in selecting participants or study respondents.

\section{Data collection}

The pretested and semistructured questionnaire used for this study was self-administered and supervised by trained research assistants. Questionnaires were proportionately allocated among classes/arms. Students were visited in their 
classes at the end of lecture periods. A total of 600 questionnaires were administered, but only 594 (99.0\%) were properly filled and analyzed. Study variables in the questionnaire included sociodemographic characteristics, sexual history, knowledge, attitude, and practice of EC.

\section{Scoring of outcome variables Knowledge score}

Ten questions on the study instrument were used to assess respondents' knowledge of EC. One mark was awarded for every correct answer and 0 marks awarded for every wrong answer. All scores were added and the mean score calculated. Respondents who scored below the mean value were categorized as having poor knowledge, while those who scored above the mean value were categorized as having good knowledge.

\section{Attitude score}

Fifteen questions on the study instrument were used to assess the respondents' attitude. One mark was awarded for a positive attitude and 0 marks for a negative attitude and undecided (indecision). All scores were added and the mean score calculated. Respondents who scored below the mean value were categorized as having poor attitude, while those who scored above the mean value were equivalent to good attitude.

\section{Data management}

The questionnaires were manually sorted and data entered into the computer. Validity of data was ensured through double entry and manual random checks. SPSS (IBM, Armonk, NY, USA) version 15 was used for data analysis. Frequency tables were generated and appropriate bivariate analysis and test statistics were applied, with significance set at $P \leq 0.05$ at a $95 \%$ confidence interval.

\section{Ethical considerations}

Ethical clearances to conduct the study were obtained from the LAUTECH Teaching Hospital ethical review committee. Permission was also obtained from the provost of each college. Informed consent was obtained from each respondent before going ahead with the study.

\section{Results}

A total of 594 out of 600 respondents returned completely filled questionnaires, giving a response rate of $99.0 \%$; $468(78.8 \%)$ respondents were between 20 and 29 years of age, with a mean age of $23.45 \pm 3.63$ years. The majority of them were females $(358,60.3 \%)$, single $(548,92.3 \%)$, Christian (473, 79.6\%), and of the Yoruba ethnic group (548, 92.3\%). (Table 1).

A total of 221 (37.2\%) of the respondents had had sex before the study, and $168(77.1 \%)$ had their first sexual intercourse between 15 and 24 years old, with a mean age of $19.34 \pm 4.34$ years. Of the 221 respondents who were sexually active, 217 responded to the question of number of sexual partners: 99 (45.6\%) had just one sexual partner, while $38(17.5 \%)$ and $80(36.9 \%)$ had two, and more than two, sexual partners, respectively. Twenty-six respondents $(21.5 \%)$ of the 121 sexually active female respondents admitted to having had an abortion (Table 2).

Table I Sociodemographic characteristics of respondents

\begin{tabular}{|c|c|c|}
\hline Variable & Frequency & Percentage \\
\hline \multicolumn{3}{|l|}{ Age-groups (years) } \\
\hline $15-19$ & 99 & 16.7 \\
\hline $20-24$ & 257 & 43.3 \\
\hline $25-29$ & 211 & 35.5 \\
\hline $30-35$ & 27 & 4.5 \\
\hline Mean age-group & $23.45 \pm 3.63$ & \\
\hline \multicolumn{3}{|l|}{ Sex } \\
\hline Male & 236 & 39.7 \\
\hline Female & 358 & 60.3 \\
\hline \multicolumn{3}{|l|}{ Marital status } \\
\hline Married & 46 & 7.7 \\
\hline Single & 548 & 92.3 \\
\hline \multicolumn{3}{|l|}{ Religion } \\
\hline Christianity & 473 & 79.6 \\
\hline Islam & 120 & 20.2 \\
\hline Others & 1 & 0.2 \\
\hline \multicolumn{3}{|l|}{ Tribe } \\
\hline Yoruba & 548 & 92.3 \\
\hline Hausa & 9 & 1.5 \\
\hline lgbo & 24 & 4.0 \\
\hline Others & 13 & 2.2 \\
\hline \multicolumn{3}{|l|}{ Institution } \\
\hline Osun State University, & 125 & 21.0 \\
\hline \multicolumn{3}{|l|}{ Osogbo Campus } \\
\hline School of Nursing, Asubiaro & 56 & 9.4 \\
\hline LAUTECH College of Health & 413 & 69.5 \\
\hline \multicolumn{3}{|l|}{ Sciences, Osogbo } \\
\hline \multicolumn{3}{|l|}{ Course of study } \\
\hline Medicine & 321 & 54.0 \\
\hline Nursing & 144 & 24.3 \\
\hline Medical laboratory technology & 38 & 6.4 \\
\hline Medical laboratory sciences & 91 & 15.3 \\
\hline \multicolumn{3}{|l|}{ Level of study } \\
\hline 100 & 135 & 22.7 \\
\hline 200 & 11 & 1.9 \\
\hline 300 & 73 & 12.3 \\
\hline 400 & 132 & 22.2 \\
\hline 500 & 133 & 22.4 \\
\hline 600 & 110 & 18.9 \\
\hline
\end{tabular}

Abbreviation: LAUTECH, Ladoke Akintola University of Technology. 
Table 2 Sexual history of respondents $(n=594)$

\begin{tabular}{|c|c|c|}
\hline Variable & Frequency & Percentage \\
\hline \multicolumn{3}{|l|}{ Had sex before } \\
\hline Yes & 221 & 37.2 \\
\hline No & 373 & 62.8 \\
\hline \multicolumn{3}{|l|}{ Age at first sex $(n=221)$} \\
\hline Less than 10 years & 5 & 2.3 \\
\hline $10-14$ years & 16 & 7.2 \\
\hline $15-19$ years & 90 & 40.7 \\
\hline $20-24$ years & 81 & 36.7 \\
\hline 25 years and above & 29 & 13.1 \\
\hline Mean age & $19.34 \pm 4.34$ years & \\
\hline \multicolumn{3}{|c|}{ Number of current sexual partners $(n=217)$} \\
\hline One & 99 & 45.6 \\
\hline Two & 38 & 17.5 \\
\hline More than two & 80 & 36.9 \\
\hline \multicolumn{3}{|l|}{ Last sexual exposure $(n=217)$} \\
\hline Within the last week & 45 & 21.1 \\
\hline Within the last month & 50 & 23.0 \\
\hline Within the last 3 months & 41 & 18.8 \\
\hline Within the last 6 months & 25 & 11.3 \\
\hline Within the last year & 30 & 13.6 \\
\hline Others & 26 & 12.2 \\
\hline \multicolumn{3}{|c|}{ Frequency of sexual intercourse $(n=217)$} \\
\hline Daily & 4 & 1.6 \\
\hline Alternate days & 29 & 13.4 \\
\hline Weekly & 38 & 17.6 \\
\hline Monthly & 51 & 23.5 \\
\hline Others & 95 & 43.9 \\
\hline \multicolumn{3}{|c|}{ Had an induced abortion (sexually active females, $n=121$ ) } \\
\hline Yes & 26 & 21.5 \\
\hline No & 95 & 78.5 \\
\hline
\end{tabular}

On the knowledge of respondents about EC, 403 (67.8\%) were aware of EC. The main source of information was from the schools in $332(55.9 \%)$ respondents, followed by from friends and magazines in 93 (15.7\%) and 84 (14.1\%), respectively. Only $184(31.0 \%)$ knew the correct timing for the use of EC. After scoring of outcome variables, $361(60.8 \%)$ respondents were categorized as having good general knowledge of EC, while 428 (72.1\%) had negative attitudes towards EC. Sixty-six (29.9\%) of the sexually active respondents had used $\mathrm{EC}$, and their main source for $\mathrm{EC}$ was the chemist (47, 71.2\%). Only 146 respondents (24.6\%) said they will use EC in future, and 147 (24.7\%) of them said they will promote its use among their friends and colleagues (Tables 3-5).

There was a statistically significant relationship between knowledge about EC and age $(P<0.00000001)$, respondents' course of study $(P<0.00000001)$, and their level in college $(P<0.00000001)$. Respondents studying medicine and those with increasing age and level in college had significantly better knowledge about EC (Table 6). Similarly, the attitude
Table 3 Knowledge of emergency contraception (EC) among respondents $(n=594)$

\begin{tabular}{lcc}
\hline Variable & Frequency & Percentage \\
\hline Possible to prevent pregnancy after unprotected sexual & intercourse \\
Yes & 479 & 80.6 \\
No & 115 & 19.4 \\
Awareness about EC & & \\
Yes & 403 & 67.8 \\
No & 191 & 32.2 \\
Source of information about EC (multiple response) & \\
School & 332 & 55.9 \\
Magazine & 84 & 14.1 \\
Friends & 93 & 15.7 \\
Family & 19 & 3.2 \\
Television/radio & 45 & 7.6 \\
Leaflet/posters & 18 & 3.0 \\
Partners & 22 & 3.7 \\
Awareness about the mechanism of action of EC & \\
Yes & 243 & 40.9 \\
No & 351 & 59.1 \\
EC can protect against HIV/STI & & \\
Yes & 46 & 7.8 \\
No & 416 & 70.0 \\
Don't know & 132 & 22.2 \\
Timing of EC usage & & 31.0 \\
Know correct timing & 184 & 60.8 \\
Do not know correct timing & 410 & \\
Categorized knowledge score & & \\
Poor & 233 & \\
Good & 361 & \\
\hline
\end{tabular}

Abbreviation: STI, sexually transmitted infection.

of the respondents towards EC was found to be statistically significantly related to their ages $(P<0.00000001)$, course of study $(P=0.0000002)$, their levels in college $(P<0.00000001)$, and their knowledge category about EC $(P<0.00000001)$ (Table 7). However, respondents' use of EC (among the sexually active) was significantly associated only with their knowledge category about EC $(P=0.017)$, such that those with better knowledge were more likely to have used EC (Table 8).

\section{Discussion}

Earlier studies in Nigeria have shown that young people are becoming more sexually liberated, ${ }^{24}$ and this was buttressed by the fact that nearly four out of ten of our respondents were sexually active. Furthermore, more than half of those sexually active had more than one sexual partner, and almost one-tenth of the female respondents had had an induced abortion. With about $40 \%$ of maternal deaths in Nigeria due to complications of unsafe abortions as a response to unwanted pregnancy, ${ }^{15,16}$ EC is therefore an important contraceptive option, especially for young people. 
Table 4 Attitude of respondents towards emergency contraception (EC) $(n=594)$

\begin{tabular}{|c|c|c|c|}
\hline Attitudinal statements & Agree & Undecided & Disagree \\
\hline EC is an important option & $406(68.4)$ & $82(13.8)$ & $106(17.8)$ \\
\hline EC is not a reliable form of contraception & $226(38.1)$ & $149(25.0)$ & $219(36.9)$ \\
\hline Women who use EC are irresponsible & $74(12.5)$ & $119(20.0)$ & $40 I(67.5)$ \\
\hline $\mathrm{EC}$ is a form of abortion & $143(24.1)$ & $119(20.0)$ & $332(55.9)$ \\
\hline Effectiveness of EC depends on correct time frame of use & $498(83.8)$ & $76(12.8)$ & $20(3.4)$ \\
\hline Effectiveness of EC depends on the type of EC used & $407(68.5)$ & $127(2 \mid .4)$ & $60(10.1)$ \\
\hline EC should be used only for rape victims & $116(19.5)$ & $82(13.8)$ & $396(66.7)$ \\
\hline EC can be used as a routine contraceptive method of choice & $178(30.0)$ & $166(27.9)$ & $250(42.1)$ \\
\hline I disapprove of use of EC by adolescents and schoolgirls & $303(51.0)$ & $90(15.2)$ & $201(33.8)$ \\
\hline EC can cause serious side effects & $297(50.0)$ & $167(28.1)$ & $130(21.9)$ \\
\hline EC can cause birth defects & $223(37.5)$ & $200(33.7)$ & $|7|(28.8)$ \\
\hline EC affects ability of users to get pregnant in the future & $140(23.6)$ & $211(35.5)$ & $243(40.9)$ \\
\hline EC can protect against pregnancy from future sex acts & $119(20.0)$ & $138(23.3)$ & $337(56.7)$ \\
\hline
\end{tabular}

Two-thirds of the respondents were aware about EC, and six out of ten respondents had good but general knowledge about EC. This level of awareness is similar to what was reported among college students in Kathmandu (66\%), ${ }^{25}$ but higher than that found in an earlier study among undergraduates in Nigeria, ${ }^{13}$ and in other African countries like Kenya, ${ }^{26}$ Ghana, ${ }^{27}$ and Cameroon. ${ }^{28}$ This may be due to the fact that many of our respondents were studying either medicine or related courses in school, and this is corroborated by the fact there was a significant relationship between knowledge about EC and the respondents' course of study in school. Knowledge about EC was also found to be significantly associated with age and level in school, such that respondents studying medicine, those in higher levels, and those with increasing age had better knowledge about EC. This corroborates similar studies from the $\mathrm{US}^{29}$ and Finland. ${ }^{30}$

Table 5 Respondents' use of emergency contraception (EC)

\begin{tabular}{lcl}
\hline Variable & Frequency & Percentage \\
\hline Used EC (among sexually active respondents, $\mathrm{n}=22 \mathrm{I})$ & \\
Yes & 66 & 29.9 \\
No & 155 & 70.1 \\
Source of EC* & & \\
Hospital & 7 & 10.6 \\
Chemist & 47 & 71.2 \\
Sexual partner & 9 & 13.6 \\
Friends & 7 & 10.6 \\
Will use EC in the future $(\mathrm{n}=594)$ & \\
Yes & 146 & 24.6 \\
No & 169 & 28.5 \\
Undecided & 279 & 47.0 \\
Will promote the usage of EC among friends $(\mathrm{n}=594)$ & \\
Yes & 147 & 24.7 \\
No & 256 & 43.1 \\
Undecided & 191 & 32.2 \\
\hline
\end{tabular}

Note: *Multiple responses.
Despite this fairly high level of awareness and good general knowledge about EC among respondents, some specific knowledge about EC, especially about the correct timing for usage, was poor, with more than six out of ten respondents not having any clue as to the correct timing of EC use. This pattern has also been reported by other studies. ${ }^{3,28}$ This shows that intensification of education of the public,

Table 6 Association between sociodemographic variables and knowledge about emergency contraception $(E C)(n=594)$

\begin{tabular}{|c|c|c|c|c|}
\hline \multirow[t]{2}{*}{ Variable } & \multicolumn{2}{|c|}{ Knowledge (\%) } & \multirow[t]{2}{*}{$\chi^{2}$} & \multirow[t]{2}{*}{$P$-value } \\
\hline & Poor & Good & & \\
\hline \multicolumn{5}{|l|}{ Age (years) } \\
\hline $15-19$ & $67(67.7)$ & $32(32.3)$ & & \\
\hline $20-24$ & $119(46.3)$ & 138 (53.7) & 76.97 & $<0.0000000 I^{*}$ \\
\hline $25-29$ & $4 I(19.4)$ & $170(80.6)$ & & \\
\hline 30 and above & $6(22.2)$ & $21(77.8)$ & & \\
\hline \multicolumn{5}{|l|}{ Sex } \\
\hline Male & $86(36.4)$ & $150(63.6)$ & & \\
\hline Female & $147(4 \mid .1)$ & $211(58.9)$ & 1.27 & 0.259 \\
\hline \multicolumn{5}{|l|}{ Marital status } \\
\hline Married & $13(28.3)$ & 33 (7I.7) & & \\
\hline Single & $220(40.1)$ & $328(59.9)$ & 2.51 & 0.113 \\
\hline \multicolumn{5}{|l|}{ Course of study } \\
\hline Medicine & $77(24.0)$ & $244(76.0)$ & & \\
\hline Nursing & $69(47.9)$ & $75(52.1)$ & 78.8 & $<0.0000000 \mathrm{I}^{*}$ \\
\hline $\begin{array}{l}\text { Medical laboratory } \\
\text { technology }\end{array}$ & $29(76.3)$ & $9(23.7)$ & & \\
\hline $\begin{array}{l}\text { Medical laboratory } \\
\text { sciences }\end{array}$ & $57(62.6)$ & $34(37.4)$ & & \\
\hline \multicolumn{5}{|l|}{ Level in college } \\
\hline 100 & $102(75.6)$ & $33(24.4)$ & & \\
\hline 200 & $6(54.5)$ & $5(45.5)$ & & \\
\hline 300 & $37(50.7)$ & $36(49.3)$ & 136.5 & $<0.0000000 I^{*}$ \\
\hline 400 & $45(34.1)$ & $87(65.9)$ & & \\
\hline 500 & $36(26.9)$ & $97(73.1)$ & & \\
\hline 600 & $8(7.3)$ & $102(92.7)$ & & \\
\hline
\end{tabular}

Note: *Statistically significant. 
Table 7 Association between sociodemographic variables and attitude towards emergency contraception (EC) $(n=594)$

\begin{tabular}{|c|c|c|c|c|}
\hline \multirow[t]{2}{*}{ Variable } & \multicolumn{2}{|c|}{ Attitude (\%) } & \multirow[t]{2}{*}{$\chi^{2}$} & \multirow[t]{2}{*}{$P$-value } \\
\hline & Negative & Positive & & \\
\hline \multicolumn{5}{|l|}{ Age (years) } \\
\hline $15-19$ & $86(86.9)$ & $13(13.1)$ & & \\
\hline $20-24$ & $200(77.8)$ & $57(22.2)$ & 35.2 & $<0.000000$ I* \\
\hline $25-29$ & $129(6||)$. & $82(38.9)$ & & \\
\hline 30 and above & $13(48.1)$ & 14 (5।.9) & & \\
\hline \multicolumn{5}{|l|}{ Sex } \\
\hline Male & $162(68.6)$ & $74(31.4)$ & & \\
\hline Female & $266(74.3)$ & $92(25.7)$ & 2.26 & 0.133 \\
\hline \multicolumn{5}{|l|}{ Marital status } \\
\hline Married & $29(63.0)$ & $17(37.0)$ & & \\
\hline Single & $399(72.8)$ & $149(27.2)$ & 2.01 & 0.156 \\
\hline \multicolumn{5}{|l|}{ Course of study } \\
\hline Medicine & $200(62.3)$ & $|2|(37.7)$ & & \\
\hline Nursing & $117(81.2)$ & $27(18.8)$ & 33.76 & $0.0000002 *$ \\
\hline $\begin{array}{l}\text { Medical laboratory } \\
\text { technology }\end{array}$ & $33(86.8)$ & $5(13.2)$ & & \\
\hline $\begin{array}{l}\text { Medical laboratory } \\
\text { sciences }\end{array}$ & 78 (85.7) & $13(14.3)$ & & \\
\hline \multicolumn{5}{|l|}{ Level in college } \\
\hline 100 & $109(80.7)$ & $26(19.3)$ & & \\
\hline 200 & $6(54.5)$ & $5(45.5)$ & & \\
\hline 300 & $62(84.9)$ & II (I5.I) & 43.32 & $<0.0000000$ \\
\hline 400 & $96(72.7)$ & $36(27.3)$ & & \\
\hline 500 & $98(73.7)$ & $35(26.3)$ & & \\
\hline 600 & $53(48.2)$ & $57(51.8)$ & & \\
\hline \multicolumn{5}{|c|}{ Categorized knowledge score } \\
\hline Poor & $168(72.2)$ & $65(27.8)$ & 71.54 & $<0.0000001 *$ \\
\hline Good & $132(36.6)$ & $229(63.4)$ & & \\
\hline
\end{tabular}

Note: *Statistically significant.

especially high-risk groups like college students, about EC still needs to be done. Health promotion, information, and education and communication programs should address areas where poor knowledge about EC has been consistently demonstrated. The main source of information for more than half of the respondents was the school. This is different from what has been previously reported, as most earlier studies reported friends and family as the major source of information about EC among college students. ${ }^{13,28}$ This finding is, however, encouraging, as the informal sources, like friends and family, have been said to be unreliable. ${ }^{28}$ In addition, many respondents could have passed through educational settings where family life health-education programs were being taught in schools.

About three-quarters of the respondents had negative attitudes towards EC, with about half disapproving of its use by adolescent girls. Nearly half of the respondents also thought EC had serious side effects, about a third of them thought EC could cause birth defects, and a quarter opined that EC is an
Table 8 Association between sociodemographic variables and usage of emergency contraception (EC) (sexually active $=221$, EC users $=66$ )

\begin{tabular}{|c|c|c|c|c|}
\hline \multirow[t]{2}{*}{ Variable } & \multicolumn{2}{|c|}{$\begin{array}{l}\text { Usage of EC among the } \\
\text { sexually active } n(\%)\end{array}$} & \multirow[t]{2}{*}{$\chi^{2}$} & \multirow[t]{2}{*}{$P$-value } \\
\hline & Used & Never used & & \\
\hline \multicolumn{5}{|l|}{ Age (years) } \\
\hline $15-19$ & $5(27.8)$ & $25(72.2)$ & & \\
\hline $20-24$ & $23(42.6)$ & $49(57.4)$ & 4.30 & 0.231 \\
\hline $25-29$ & $33(42.3)$ & $63(57.7)$ & & \\
\hline 30 and above & $5(35.7)$ & $18(64.3)$ & & \\
\hline \multicolumn{5}{|l|}{ Sex } \\
\hline Male & $29(39.7)$ & 7I (60.3) & & \\
\hline Female & $37(40.7)$ & $84(59.3)$ & 0.07 & 0.799 \\
\hline \multicolumn{5}{|l|}{ Marital status } \\
\hline Married & $10(32.3)$ & $36(67.7)$ & & \\
\hline Single & $56(42.1)$ & $119(57.9)$ & 1.83 & 0.176 \\
\hline \multicolumn{5}{|l|}{ Level in college } \\
\hline 100 & II (32.4) & $4 I(67.6)$ & & \\
\hline 200 & $3(45.5)$ & $8(54.5)$ & & \\
\hline 300 & $8(34.8)$ & $21(65.2)$ & 8.16 & 0.148 \\
\hline 400 & $8(40.0)$ & $20(60.0)$ & & \\
\hline 500 & $14(36.6)$ & $39(63.4)$ & & \\
\hline 600 & $22(50.0)$ & $26(50.0)$ & & \\
\hline \multicolumn{5}{|c|}{ Categorized knowledge } \\
\hline Poor & $22(19.8)$ & $89(80.1)$ & 10.74 & $0.00 I^{*}$ \\
\hline Good & $44(40.0)$ & $66(60.0)$ & & \\
\hline \multicolumn{5}{|c|}{ Categorized attitude } \\
\hline Negative & $42(28.4)$ & I06 (7I.6) & 0.47 & 0.492 \\
\hline Positive & 24 (32.9) & $49(67.1)$ & & \\
\hline
\end{tabular}

Note: *Statistically significant.

abortifacient and/or a form of abortion, while others thought that $\mathrm{EC}$ is an unimportant form of contraception. Thus, it is clear why the practice of EC among this target group considered to be at high risk for unwanted pregnancy is low: this is because of their poor comprehensive knowledge and attitude. This is similar to a study done among female undergraduates in Eastern Nigeria, where it was believed that increased utilization of EC is plagued with fear of infertility anovulation, ill health, and sexually transmitted infection. ${ }^{31}$ Hence, their practice of EC was low. Similar concerns have been reported by other studies, ${ }^{31-34}$ and this underscores the need for proper education of the public about EC, especially addressing these common misconceptions. This is corroborated by the fact that there was a significant association between knowledge about, and attitude towards, EC: those with better knowledge had positive attitudes towards EC. Emergency contraception thus needs to be presented and positioned as an option that is safe and effective. ${ }^{6,7}$

Only about one-third (29.9\%) of the sexually active respondents had ever used EC by the time of the study, and this is lower than the $35.5 \%$ previously reported by Akani et al 
in the Niger Delta region of Nigeria, ${ }^{13}$ but higher than what was reported from Cameroon (7.4\%), ${ }^{28}$ Uganda (2\%), ${ }^{2}$ and South Africa (4\%). ${ }^{3}$ The use of EC is generally low, and this confirms the fact that EC is largely underutilized worldwide and has been referred to as one of the best-kept secrets in reproductive health. ${ }^{2,89}$ This, however, is a cause for concern, because unintended pregnancies and consequent abortions constitute serious health challenges in developing countries like Nigeria. ${ }^{13,15,16}$ Viewed against the background of the fact that almost a quarter (21.5\%) of the sexually active female respondents in this study had abortions, this calls for urgent action. The World Health Organization estimates that 84 million unwanted pregnancies occur annually worldwide. ${ }^{11}$ In Nigeria, a study found that abortion was one of the three major causes of death. ${ }^{35}$ If knowledge of EC is widespread among the high-risk group, it will impact on its uptake and thus contribute to reducing the rate of unwanted pregnancies and their consequent complications. This finding also stressed the need for continuous and sustained health-promotion and education programs targeted at youths in Nigeria, as well as making our family planning programs and services more youth-friendly.

\section{Conclusion and recommendations}

In spite of the fairly high level of awareness, lack of comprehensive knowledge of EC, especially about appropriate timing of usage, coupled with a high level of negative attitudes toward EC translated into a very low level of usage of $\mathrm{EC}$ among the respondents. The reported high incidence of premarital sexual activity and poor use of EC among Nigerian undergraduates calls for EC as a second-chance approach if the incidence of unintended pregnancy and clandestine abortions are to be kept to the barest minimum. In order to reduce the gap between knowledge and utilization of emergency contraceptives, there is a need for health-education initiatives about EC targeting students and addressing specific areas of poor knowledge. Extensive campaigns through seminars, television talk shows, radio programs, school-based programs, and printed media should be employed to encourage a positive attitudinal change and improve the utilization of EC among undergraduates in Nigeria.

\section{Disclosure}

The authors report no conflicts of interest in this work.

\section{References}

1. Jamieson MA, Hertweck SP, Sanfilippo JS. Emergency contraception: lack of awareness among patients presenting for pregnancy termination. J Pediatr Adolesc Gynecol. 1999;12(1):11-15.
2. Byamugisha JK, Mirembe FM, Gemzell-Danielsson EFK. Emergency contraception and fertility awareness among university students in Kampala, Uganda. Afr Health Sci. 2006;6(4):194-200.

3. Myer L, Mlobeli R, Cooper D, Smit J, Morroni C. Knowledge and use of emergency contraception among women in the Western Cape province of South Africa: a cross-sectional study. BMC Womens Health. 2007;7(14):1-7.

4. Grimes DA. Switching emergency contraception to over-the-counter status. $N$ Engl J Med. 2002;347(11):846-849.

5. Trussell J, Calabretto H. Cost savings from use of emergency contraceptive pills in Australia. Aust N Z J Obstet Gynaecol. 2005;45(4):308-311.

6. Trussell J, Rodriguez G, Ellertson C. Updated estimates of the effectiveness of the Yuzpe regimen of emergency contraception. Contraception. 1999;59(3):147-151.

7. Graham A, Moore L, Sharp D, Diamond I. Improving teenagers' knowledge of emergency contraception: cluster randomised controlled trial of a teacher led intervention. BMJ. 2002;324(7347):1179.

8. Gemzell-Danielsson K, Marions L. Mechanisms of action of mifepristone and levonorgestrel when used for emergency contraception. Hum Reprod Update. 2004;10(4):341-348.

9. Trussell J, Ellertson C, Stewart F, Raymond EG, Shochet T. The role of emergency contraception. Am J Obstet Gynecol. 2004;190(4 Pt 2): $\mathrm{S} 30-\mathrm{S} 38$.

10. Physicians for Reproductive Choice and Health (PRCH), Alan Guttmacher Institute (AGI). An Overview of Abortion in the United States. New York: PRCH, AGI; 2003.

11. World Health Organization (WHO). Unsafe Abortion: Global and Regional Estimates of the Incidence of Unsafe Abortion and Associated Mortality in 2004. Geneva: WHO; 2004.

12. Segal SJ, LaGuardia KD. Termination of pregnancy: a global view. Baillieres Clin Obstet Gynaecol. 1990;4(2):235-247.

13. Akani CI, Enyindah CE, Babatunde S. Emergency contraception: knowledge and perception of female undergraduates in the Niger Delta of Nigeria. Ghana Med J. 2008;42(2):68-70.

14. Abe E, Omo-Aghoja LO. Maternal mortality at the Central Hospital, Benin City Nigeria: a ten year review. Afr J Reprod Health. 2008;12(3): $17-26$.

15. Adewale IF. Trends in postabortal mortality and morbidity in Ibadan, Nigeria. Int J Gynecol Obstet. 1992;38(2):115-118.

16. Omo-Aghoja LO, Omo-Aghoja VW, Aghoja CO, et al. Factors associated with the knowledge, practice and perceptions of contraception in rural southern Nigeria. Ghana Med J. 2009;43(3):115-121.

17. Sander PM, Raymond EG, Weaver MA. Emergency contraceptive use as a marker of future risky sex, pregnancy and sexually transmitted infection. Am J Obstet Gynecol. 2009;201(2):146. e1-e6.

18. Oladapo OT, Adefuye PO, Odusoga OL, Okewole IA, Daniel OJ. Emergency contraception among female undergraduates in Ogun state, Nigeria. Sex Health Matters. 2005;6(4).

19. Arowojolu AO, Adekunle AO. Perception and practice of emergency contraception by post-secondary school students in southwest Nigeria. Afr J Reprod Health. 2000;4(1):56-65.

20. Roberts C, Moodley J, Esterhuizen T. Emergency contraception: knowledge and practices of tertiary students in Durban, South Africa. J Obstet Gynaecol. 2004;24(4):441-445.

21. Aziken ME, Okonta PI, Ande AB. Knowledge and perception of emergency contraception among female Nigerian undergraduates. Int Fam Plann Persp. 2003;29(2):84-87.

22. Soon JA, Levine M, Osmond BL, Ensom MHH, Fielding DW. Effects of making emergency contraception available without a physician's prescription: a population-based study. CMAJ. 2005;172(7):877-883.

23. Cheng L, Gulmezoglu AM, Oel CJ, Piaggio G, Ezcurra E, Look PF. Interventions for emergency contraception. Cochrane Database Syst Rev. 2004;3:CD001324.

24. Olugbenga-Bello AI, Adekanle DA, Ojofeitimi EO, Adeomi AA. Barrier contraception among adolescents and young adults in a tertiary institution in Southwestern Nigeria: a cross-sectional descriptive study. Int $J$ Adolesc Med Health. 2010;22(2):321-329. 
25. Adhikari R. Factors affecting awareness of emergency contraception among college students in Kathmandu, Nepal. BMC Womens Health. 2009;9(27):1-5.

26. Muia E, Ellertson C, Lukhando M, Flul B, Clark S, Olenia J. Emergency contraception in Nairobi, Kenya: knowledge, attitude and practices among policy makers, family planning providers and clients, and university students. Contraception. 1999;60(4):223-232.

27. Baiden F, Awini E, Clerk C. Perception of university students in Ghana about emergency contraception. Contraception. 2002;66(1):23-26.

28. Kongnyuy EJ, Ngassa P, Fomulu N, Wiysonge CS, Kouam L, Doh AS. A survey of knowledge, attitudes and practice of emergency contraception among university students in Cameroon. BMC Emerg Med. 2007;7(7):1-7.

29. Vahratian A, Patel D, Wolff K, Xu X. College students' perceptions of emergency contraception provision. J Womens Health. 2008;17(1): 103-111.

30. Falah-Hassani K, Kosunen E, Shiri R, Rimpelä A. Emergency contraception among Finnish adolescents: awareness, use and the effect of non-prescription status. BMC Public Health. 2007; 7:201.
31. Abasiattai AM, Umoiyoho AJ, Bassey EA, Etuk SJ, Udoma EJ. Misconception of emergency contraception among tertiary school students in Akwa Ibom State, South-south, Nigeria. Niger J Clin Pract. 2007;10(1):30-34.

32. Abdulghani HM, Karim SI, Irfan F. Emergency contraception: knowledge and attitudes of family physicians of a teaching hospital, Karachi, Pakistan. J Health Popul Nutr. 2009;27(3):339-344.

33. Sufrin CB, Tulsky JP, Goldenson J, Winter KS, Cohan DL. Emergency Contraception for Newly Arrested Women: Evidence for an Unrecognized Public Health Opportunity. J Urban Health. 2010; 87(2):244-253. Epub December 12, 2009.

34. Ikeme AC, Ezegwui HU, Uzodimma AC. Knowledge, attitude and use of emergency contraception among female undergraduates in Eastern Nigeria. J Obstet Gynaecol. 2005;25(5):491-493.

35. Unuigbe JA, Oronsaye AU, Orhue AA. Abortion-related morbidity and mortality in Benin City, Nigeria: 1973-1985. Int J Gynaecol Obstet. $1988 ; 26(3): 435-439$.
Open Access Journal of Contraception

\section{Publish your work in this journal}

Open Access Journal of Contraception is an international, peerreviewed, open access, online journal, publishing original research, reports, reviews and commentaries on all areas of contraception. In addition to clinical research, demographics and health-related aspects, the journal welcomes new findings in animal and preclinical studies

\section{Dovepress}

relating to understanding the biological mechanisms and practical development of new contraceptive agents. The manuscript management system is completely online and includes a very quick and fair peer-review system. Visit http://www.dovepress.com/testimonials.php to read real quotes from published authors. 